\title{
Impact of Enriched Biochar on Bean Growth (Phaseolus vulgaris) in the Presence of Mycorrhizae on two Contrasting Soils of Ngaoundere (Cameroon)
}

\author{
Hassana Boukar \\ University Institute of Technology (UIT) \\ Ngaoundere, Cameroon \\ Ngassoum Martin \\ National Advanced School of Agro-process Industries \\ (ENSAI) \\ Ngaoundere, Cameroon
}

\author{
Barka Abakoura \\ Polytechnic University of Mongo \\ Chad \\ Mbawala Augustin \\ National Advanced School of Agro-process Industries \\ (ENSAI) \\ Ngaoundere, Cameroon
}

\author{
Ibrahima Adamou \\ Faculty of Sciences, Ngaoundere, Cameroon \\ Ngaoundere, Cameroon
}

\begin{abstract}
Although the use of mycorrhizae increases the agricultural yield, its cost remains prohibitive. The objective of this study is to evaluate the effect of the use of enriched biochar on the level of mycorrhizae applied on two contrasting soils. The enriched biochar is obtained by the pyrolysis of a mixture of sawdust, clay, and chicken manure. Experiments are carry out by growing French beans in pots containing two different soils collected in Ngaoundéré (University campus and Beka). A randomized bloc factorial design based on six mycorrhizae treatments and two soil samples is used. Measured parameters are the germination duration; the total mass of stalks and roots; the roots depth; the increase in stalks height and diameter, the increase of the cumulative leaves number, the production of pods, and thus the yield. The university campus soil presents an acidic pH (5.2 \pm 0.2$)$, meanwhile Beka soil shows an alkaline pH (7.75 \pm 0.1$)$. When using enriched biochar, the germination' duration is significantly improved with the acidic soil (p<0.01) unlike that of the alkaline soil. Also, the total mass of the stalks and that of the roots are highly improved by the use of enriched biochar on the acidic soil compared to the alkaline soil. The same trends are observed for the production of cloves. Definitely, the enriched Biochar ameliorates the production of French beans on acidic soils and enables to reduce the level of mycorrhizae introduced in this type of soil.
\end{abstract}

Keys words- Enriched biochar; French bean; Mycorrhizae; acidic soil; alkaline soil.

\section{INTRODUCTION}

The French bean (Phaseolus vulgaris) is cultivated by Central African populations mainly because of its high protein content $[1 ; 2]$. In Cameroon, this leguminous crop occupies the largest surface area compared to other crops [3; 4]. The National demand continues to grow over time due to population growth, while yields remain low. This is attributed to several constraints, among which is the poor soil fertility [5]. While the use of chemical fertilizers can increase yields, it can also lead to soil acidification and soil water pollution. The use of biofertilizers such as mycorrhiza has appeared to be a promising alternative [6]. Mycorrhizal fungi can improve soil structure [7; 8;9]. They have the ability to colonize not only the rhizosphere but also the soil beyond it [7]. Their filaments coming into contact with the roots will provide them with nutrients and water. Plant growth is strongly stimulated. For example, a significant increase in above-ground and root biomass and better resistance to soil antagonists is reported $[10 ; 11 ; 12]$. It thus appears that, it is possible to reduce chemical fertilizers inputs while preserving the yield. The use of mycorrhizae, however, comes in with two constraints. Mycorrhizae require some soil physicochemical conditions for their colonization $[13 ; 14]$. On the other hand, the use of mycorrhiza is prohibitive and this considerably reduces the profit margin of farmers. It therefore become imperative to look for other ways to increase agricultural profitability while reducing the environmental impact of this type of anthropogenic activity.

In order to improve agricultural profitability, and to reduce food insecurity due to protein shortages, one of the approaches advocated in recent years to produce food in a sustainable way is the combination of the two biofertilizers; biochar and mycorrhiza $[15 ; 16 ; 17 ; 18]$.

The biochar obtained by pyrolysis and from various materials, makes it possible, among other things, to stabilize certain acidic and poor tropical soils [19; 20]. It therefore contributes to improving the agronomic performance of these crops [21]. It significantly improves many of the physicochemical properties of soil by increasing its alkalinity, water retention potential, cation exchange capacity $[22 ; 23 ; 25 ; 21]$. 
It has been shown that in the presence of biochar, the symbiotic effect between plants and mycorrhizal fungi increases [10;25]. Mycorrhizae would provide larger amounts of nutrients such as phosphorus, nitrogen and zinc to plants [26; 27; 28; 29]. Also, the biochar through its numerous pores, can serve as habitat and refuge against predators of mycorrhizal fungi [25; 30; 31 ; 32].

The present study is aiming at testing a combination of enriched biochar and various levels mycorrhizae on French beans cultivated on two different soil samples (an acidic soil, and an alkaline soil). The main purpose is to minimize mycorrhizae incorporation into soils, thereby reducing production cost and improving farming profitability.

\section{MATERIAL AND METHODS}

\section{A. Material}

French beans seeds (Phaseolus vulgaris), also called red beans of the improved variety GLP 190 from the IRAD of Dschang (Cameroon) is used. It is a non-climbing dwarf variety with a 75-day production cycle [33; 34].

The mycorrhizal inoculum used for this work is purchased at the Biotechnology Research Laboratory of the University of Yaounde I (Cameroon). It consists of a mixture of soil (clay, sand grains), root fragments with fungal spores of the genus Glomus and Gigaspora at a concentration of 7 spores/g. These mycorrhizal strains were identified by Nwaga [6].

The enriched biochar used for this study is obtained from a mixture of $53 \%$ sawdust powder of Ayous essence (Triplochiton scleroxylon), 30\% of Wak clay powder and $17 \%$ of the chicken manure powder. The choice of these proportions for the enriched biochar formulation is obtained by using a mixture design. The biochar production conditions are a temperature of $550^{\circ} \mathrm{C}$ and a residence time of 2 hours in an electric furnace Nagat (Montoir de Bretagne, France).

Water $\mathrm{pH}$ measurement was performed according to the method of Rajkovich et al. [35]. Granulometric analysis was determined by the Robinson's pipette method [36]. The electrical conductivity of the soil samples was carried out according to standard NF ISO 11265 [37]. The cation exchange capacity (CEC) was determined according to the standardized method [38]. Total nitrogen is determined after mineralization of the samples by Kjeldahl method [39; 40]. Determination of total phosphorus is done by using the method described by Rodier [41]. Calcium and magnesium are determined by the titrimetric method [42].

Plastic pots, $25 \mathrm{~cm}$ high and $3.5 \mathrm{~cm}$ in radius, or about $960 \mathrm{~cm} 3$, is used for sowing and growing bean plants.

Soil samples are collected from two sites. The first site is located on the campus of the University of Ngaoundere, behind the medical and social center (Cartesian coordinates: N07 $18^{\prime} 781^{\prime \prime}$, E13 $35^{\prime} 634^{\prime \prime}$, raised to 1096m). The site is an abandoned field, because of the poor yield according to the local residents. The site has a reddish-brown, ferralitic-type soil grown on basalt [43]. The second soil is collected from a site about ten kilometers from downtown Ngaoundere, in a locality called Beka (Cartesian coordinates: $\mathrm{N}^{\circ} 7^{\circ} 19^{\prime} 051^{\prime}$, E $13^{\circ} 35^{\prime} 027^{\prime}$ ', raised to $1110 \mathrm{~m}$ ). It is a basic type soil, rich in organic matter [44; 45] where farmers have been cultivating red beans for more than three decades.

\section{Experimental design}

Experiments are carried out during three vegetation periods on the soils described above. Six treatments are performed including the control (without $0 \%$ biochar and $0 \%$ mycorrhizal) and five other treatments with the same proportion of biochar $(10 \%)$ but varying proportions of mycorrhizae $(0 \%, 1 \%, 2 \% ; \%$ and $4 \%)$. Each treatment has three repetitions. All trials are randomly distributed among the three rows of experimental pots. Each pot represents an experimental unit for a total of 36 experimental units. A complete randomized device is applied for this study. The experimental planning is a complete randomized bloc factorial design of mycorrhizal treatments and soil types (factorial 6x2).

\section{B. Methods.}

\section{Sampling and soil preparation}

Soil samples are collected from two sites during the months of September and October. Samples are taken according to the method described by Beesley and Marmiroli [46] and Mathieu and Pieltain [47]. The samples are collected at a depth of 20 $\mathrm{cm}$ from the surface using a shovel. In order to obtain a reliable result, 15 elementary samples are taken from the plot. A diagonal sampling method that is adopted.

Potted trials

Principle

The method used to evaluate impacts on the growth of bean plants is adapted from that of Saxena et al. [48]. Bean seeds are sown in pots without biochar and mycorrhiza (control soil) and in different proportions of $0 \% ; 1 \% ; 2 \% ; 3 \% 4 \%$ mycorrhizae (w/w). The control soil contains exclusively soil. Except for the control soil, the other treatments received a constant mass of biochar $50 \mathrm{~g}$ representing a $10 \%$ incorporation and a constant soil mass of $500 \mathrm{~g}$. Thus, the modification of the mass provided by the addition of the biochar is not taken into account, the proportion of the biochar being very small compared to the mass of soil (Table 1). 
Table 1: Different Mixtures for Seedling and Bean Growth

\begin{tabular}{|l|c|c|c|c|c|c|}
\hline Pots code & control & $\begin{array}{c}10 \% \mathrm{~EB}+0 \% \\
\text { MP }\end{array}$ & $\begin{array}{c}10 \% \mathrm{~EB}+1 \% \\
\text { MP }\end{array}$ & $\begin{array}{c}10 \% \mathrm{~EB}+2 \% \\
\text { MP }\end{array}$ & $\begin{array}{c}10 \% \mathrm{~EB}+3 \% \\
\text { MP }\end{array}$ & $\begin{array}{c}10 \% \mathrm{~EB}+4 \% \\
\text { MP }\end{array}$ \\
\hline Soil $[\mathrm{g}]$ & 500 & 500 & 500 & 500 & 500 & 500 \\
\hline Biochar $[\mathrm{g}]$ & 0 & 50 & 50 & 50 & 50 & 50 \\
\hline Mycorrhizea $[\mathrm{g}]$ & 0 & 0 & 5 & 10 & 15 & 20 \\
\hline Mycorrhizea $[\%]$ & 0 & 0 & 1 & 2 & 3 & 4 \\
\hline
\end{tabular}

Legend: $M P=$ Mycorrhizea's Proportion, $E B=$ Biochar enriched

Preparation of pots and seedlings

The various constituents (soil, enriched biochar and mycorrhiza) of the pots are mixed manually. The bean seeds are sown to a depth of $1 \mathrm{~cm}$. These are the seeds of good physical shape that are chosen. It is an under shelter culture. Three replicates are made per test with one bean grain per pot. A quantity of distilled water $(300 \mathrm{ml})$ is watered every 72 hours.

\section{Study of the influence of enriched biochar in the presence of different proportions of mycorrhiza on bean production}

Follow-up of some plant parameters

The follow-op of plant growth consisted of knowing the germination time, the progression of the stalk size, the increase of the size diameter of the stem at the collar and finaly the progression of the leaves' number. The collar is the transition zone between the stem and the root of a plant. All results are averages of three trials. The duration of germination is the time taken by the plant to germinate. Weekly measurements of plant size is done using a tape measure. The diameter at the collar of the stem is also done weekly by using a calliper. The number of leaves is determined weekly by counting the leaves of the plants in each pot.

Increase of the dry biomass mass of different parts of the plant.

The weight of the dry biomass of the stem, roots and pods is carry out at the same time. It consisted of the destruction of the plant in its three parts that are the stem, the roots and the pods. The bean pods are dried at room temperature to facilitate separation of bean seeds. These are separated by hand, then placed in nacelles and placed in an oven at $105^{\circ}$ for 24 hours for the determination of the dry matter.

Statistical analyses.

The results are statistically analysed using the "Stratigraphic Centurion" software version 18. The averages are compared using ANOVA. Turkey's Honestly Significant Difference (HSD) is chosen to determine the difference between treatment averages.

\section{III. $\quad$ RESULTS AND DISCUSSIONS}

\section{Characterization of soils and enriched biochar}

Table 2 presents some physicochemical characteristics of the studied soils and enriched biochar. The university campus soil is acidic ( $\mathrm{pH}$ between 5.11 and 5.46) with an average of $5.2 \pm 0.2$, while that of Beka is basic (pH between 7.64 and 7.83 ) with a mean value of $7.75 \pm 0.1$. The water content means comparison of the two soils and the enriched biochar reveals significant differences $(p<0.001)$. The Tukey HSD test distinguishes three groups representing the three substrates studied. The same observation is made for most of the other studied parameters. The $\mathrm{pH}$ values of Beka soil are close to those obtained by Fezeu (2006) but differ from those reported by Rippstein (1985). The average $\mathrm{pH}$ of the biochar is $(9.2 \pm 0.3)$. The enriched biochar shows the highest and most basic $\mathrm{pH}$ of both soils. The soils and the enriched biochar are significantly different at $\mathrm{p}<0.05$. The acidity of the university campus soil can be attributed to the origin of the parent material made up of granites. Another explanation is the abundance of iron and aluminium ions that result in the red colour of this soil. Another explanation is the strong water erosion, which prevents the constitution of a richness in organic matter. The acidic nature of the university campus soil results in increased mobility of cations that can be leached to surface or groundwater. The unavailability of these nutrients makes this soil to be poor. Acidic soils are often associated with poor soils and have many drawbacks, such as stopping underground microbial activity, hindering certain nutrients uptake plants. These soils can also cause growth disturbance, appearance of toxicity related to metals absorption such as aluminium (made more soluble in acidic soil). The parent material can explain the basic character of Beka soil. Indeed, this soil is derived from an ancient basalt [45]. It is a priori favourable to agricultural practices, and that is why we choose it to grow the beans. The majority of biochars are basic; the incorporation of chicken droppings and clay makes them more basic This strong basicity is suitable for use as a liming agent. It can be predicted that a small proportion of enriched biochar could increase the $\mathrm{pH}$ and reduce soil acidity [49]. 
Table 2: Physicochemical characteristics of soil and enriched biochar

\begin{tabular}{|c|c|c|c|c|}
\hline Parameters & S1 & S2 & EB & $p$ value \\
\hline pH & $7,75 \pm 0,1^{\mathrm{b}}$ & $5,2 \pm 0,2^{\mathrm{c}}$ & $9,20 \pm 0,3^{\mathrm{a}}$ & $\mathrm{p}<0,001$ \\
\hline $\mathbf{E C}_{1 / 5}\left[\mu \mathrm{S} . \mathrm{cm}^{-1}\right]$ & $75,00 \pm 4,3^{\mathrm{a}}$ & $11,07 \pm 0,5^{\mathrm{c}}$ & $47,75 \pm 1,7^{\mathrm{b}}$ & $\mathrm{p}<0,001$ \\
\hline OM [\%] & $15,33 \pm 0,95^{\mathrm{b}}$ & $11,74 \pm 0,95^{\mathrm{c}}$ & $33,80 \pm 0,7^{\mathrm{a}}$ & $\mathrm{p}<0,001$ \\
\hline $\mathrm{CEC}\left[\mathrm{cmol}_{\mathrm{c}} \mathrm{kg}^{-1}\right]$ & $27,78 \pm 5^{\mathrm{b}}$ & $8,82 \pm 6^{c}$ & $35 \pm 5^{\mathrm{a}}$ & $\mathrm{p}<0,001$ \\
\hline Sand content [\%] & $30,38 \pm 1,4^{\mathrm{b}}$ & $59,46 \pm 1,4^{\mathrm{a}}$ & - & \\
\hline Slit content [\%] & $16,67 \pm 1,6^{\mathrm{a}}$ & $10,29 \pm 1,7^{b}$ & - & \\
\hline Clay content $[\%]$ & $52,95 \pm 1,5^{\mathrm{a}}$ & $30,25 \pm 1,4^{\mathrm{b}}$ & - & \\
\hline Soil's Texture & $\mathrm{C}$ & S-C-L & - & \\
\hline org Carbone \% & $2,25 \pm 0,05^{\mathrm{b}}$ & $0,81 \pm 0,05^{\mathrm{c}}$ & $23,6 \pm 0,07^{\mathrm{a}}$ & $\mathrm{p}<0,001$ \\
\hline $\mathbf{N}$ djedahl $\%$ & $0,17 \pm 0,03^{\mathrm{b}}$ & $0,04 \pm 0,01^{\mathrm{c}}$ & $1,82 \pm 0,01^{\mathrm{a}}$ & $\mathrm{p}<0,001$ \\
\hline P totals $\left[\mu \mathrm{g} . \mathrm{g}^{-1}\right]$ & $10,68 \pm 0,5^{\mathrm{b}}$ & $2,51 \pm 0,4^{\mathrm{c}}$ & $15 \pm 0,4^{\mathrm{a}}$ & $\mathrm{p}<0,001$ \\
\hline Ca totals $\left[\mu \mathrm{g} . \mathrm{g}^{-1}\right.$ ] & $8,8 \pm 0,5^{\mathrm{b}}$ & $1,6 \pm 0,4^{c}$ & $11,55 \pm 0,4^{a}$ & $\mathrm{p}<0,001$ \\
\hline Mg totals [ug.g ${ }^{-1}$ & $2,3 \pm 0,4^{\mathrm{b}}$ & $0,85 \pm 0,1^{\mathrm{c}}$ & $3,67 \pm 0,3^{\mathrm{a}}$ & $\mathrm{p}<0,001$ \\
\hline
\end{tabular}

The values followed by the same lowercase letters are not significantly different; the values of p are calculated at different percentages and reported in a column Legend: $S 1$ = Beka's soil; $S 2$ = campus University's soil; $E B=$ enriched Biochar; $p$ = probability; EC = electrical conductivity; CEC = cation exchange capacity, $O M=$ organic matter; $A$. $C=$ ash content, $C=$ clay; $S-C-L=$ sandy clay loam.

University campus soil electrical conductivity range from 10.6 to $11.7 \mu \mathrm{S} . \mathrm{cm}-1$ with an average of $11.7 \mu \mathrm{S} . \mathrm{cm}-1$. That of the Beka soil is greater; it varies from $70.1 \mu \mathrm{S} . \mathrm{cm}-1$ to $78.3 \mu \mathrm{S} . \mathrm{cm}-1$ with an average of $75.00 \mu \mathrm{S} . \mathrm{cm}-1$. The enriched biochar revealed conductivity values between the studied contrasting soils. The measured extended values are between $46.11 \mu \mathrm{S} . \mathrm{cm}-1$ and $49.57 \mu \mathrm{S} . \mathrm{cm}-1$. Reflecting the total amount of ions in solution, the averages of the two studied soils and that of enriched biochar could not affect the plants growth according to the Durand scale [50]. The values are all included in class 1, i.e. less than $500 \mu \mathrm{S} . \mathrm{cm}^{-1}$ and therefore any type of plant can easily grow in these environments because the absorption of water will not be stopped. Rich in minerals, the enriched biochar could increase the electrical conductivity of the university campus soil, but neither that of Beka. The latter has a higher electrical conductivity than the enriched biochar.

Water eroded soils have a lower organic matter content. This is the case of the university campus soil where its content is $11.74 \pm 0.95 \%$, while that of the Beka has an average content of $15.33 \pm 0.95 \%$. The results differ from those obtained by Adjia in 2010 [51] or Noubissié in 2015 [52]. The university campus soil is marginalized and abandoned for its poor performance. The slight difference $(4 \%)$ in terms of organic matter content between the university campus soil and that of Beka can be explained by the fact that the harvesting residues of bean grains enrich the latter, which constitutes therefore an important source of organic matter supply.

Cation exchange capacity ranged from $8.82 \pm 6 \mathrm{cmol}_{\mathrm{c} . \mathrm{kg}^{-1}}$ (university campus soil) to $27.78 \pm 5 \mathrm{cmol}_{\mathrm{c}} \cdot \mathrm{kg}^{-1}$ (Beka soil) versus $35 \pm 5 \mathrm{cmol}_{\mathrm{c}} \cdot \mathrm{kg}^{-1}$ for the enriched biochar. Noubissié [52] obtained higher values for grower soils in Ngaoundere. This difference can be explained by the abundant organic matter richness of vegetable soils. Beka's soil has a cation exchange capacity that is more than twice as high as the university campus. There are two reasons for this superiority. The first is the original material of two soils. The campus floor is of granitic origin and the Beka soil is of basaltic origin. The second explanation is the superiority of Beka's soil in organic matter. In general, pyrolysis increases the porosity and thereby the cation exchange capacity of the carbonized organic substrates. Enrichment by incorporation of chicken manure and clay from Wak substantially increased the cation exchange capacity of biochar from sawdust.

The granulometric analysis of the two soils studied reveals some minor differences between the two soils. The sand content of the two soils is respectively $30.38 \% \pm 1.4$ and $59.46 \% \pm 1.4$ for the Beka soil and the university campus respectively. If the sand, by its relative large volume, does not contribute to the fertility of the soil, the silt and the sand make it possible, by their strong nutriments adsorption capacity, to increase the yield of the cultures. The proportion of Beka soils and university campus silts is $16.67 \pm 1.6$ and $10.29 \pm 1.7$ per cent, respectively. The average clay proportion is $52.95 \% \pm 1.5$ and $30.25 \pm 1.4$ respectively for Beka soil and university campus soil. This difference is significant. This difference $(p<0.05)$ makes it possible to classify the Beka soil as clay soil and that of the university campus as a sandy clay soil. This difference also makes it possible to assert a higher fertility to the Beka soil even though a mineralogical analysis of the clay from the two sites may be necessary to confirm this observation. The quality of the clay is an important factor in assessing the ability of the soil to increase crop yield.

The nitrogen content of the enriched biochar is greater than that of both soils. It is $1.82 \% \pm 0.01$ for enriched biochar against $0.17 \% \pm 0.03$ and $0.04 \% \pm 0.01$ for Beka soil and university campus soil respectively. The very high proportion of nitrogen in the enriched biochar compared to the two studied soils probably because of the nitrogen brought by the chicken manure. The Beka soil has a greater nitrogen proportion compared to the university campus soil because the agricultural practices on this soil leaves a large amount of crop residues rich in nitrogen. On the university campus soil, the cultural background is rather the cultivation of corn.

Macronutrients are important in plant nutrition. The phosphorus contents are $15 \% \pm 5.4$ for the enriched biochar, against $10.68 \% \pm 5.5$ and $2.51 \% \pm 3.4$ for Beka and university campus soils respectively. These values significantly differ from each 
other at $\mathrm{p}<0.01$. The enriched biochar has a higher phosphorus content because of the addition of chicken manure and clay during the incorporation. The Beka soil has a higher phosphorus content than the university campus soil because of their bedrock materials, the first from granite and the latter from basalt. On the other hand, the proximity of the site of Beka that adjoins the volcanic crater of Lake Tyson. Under the action of wind erosion, particles of volcanic rocks usually rich in phosphate can enrich the Beka soil. In addition, a lower available phosphorus content could accompany the low total phosphorus content of the university campus soil. The iron and aluminium hydroxides detectable by the soil red colour can adsorb a significant amount of phosphates and form compounds with very little solubility in tropical acid soils. These compounds are unavailable to plants [53]. However, microorganisms can solubilize these forms, provided they have an available source of carbon. Biochar that has a high carbon content could be helpful.

The calcium contents vary from $8.8 \% \pm 0.5 \mu \mathrm{g}$.g- 1 for Beka soil to $1.6 \% \pm 0.4 \mu \mathrm{g} . \mathrm{g}-1$ for university campus soil. The enriched biochar presents a higher content with $11.55 \pm 0.4 \mu \mathrm{g}$.g- 1 . The calcium content of the Beka soil makes it possible to have an aggregated soil structure because calcium allows flocculation of different soil particles. The low calcium content of the soil does not improve the soil structure, which still remains in the form of particles. This tendency is weakened further in the presence of iron and aluminium oxyhydroxides when the soil is acidic. This is the case with the abandoned university campus soil. The high calcium content of the enriched biochar could improve soil structure.

The total magnesium content are $2.3 \pm 0.4 \mu \mathrm{g} \cdot \mathrm{g}^{-1}$ and $0.85 \pm 0.1 \mu \mathrm{g} \cdot \mathrm{g}^{-1}$ for the Beka soil and the university campus soil respectively. The enriched biochar has a total magnesium content of $3.67 \pm 0.3 \mu \mathrm{g} . \mathrm{g}^{-1}$. Magnesium is more likely to be leached than potassium because it is poorly retained by clays.

\section{Combined effect of enriched biochar and proportion of incorporated mycorrhizae on some bean growth parameters.}

Tables 3 and 4 show the influence of biochar and proportions of incorporated mycorrhizae on the university campus soil and Beka soil. The parameters presented in this table are the duration of emergence, the total mass of stems and roots dry matter, and the root size. These parameters were measured once. The duration of emergence is measured at the beginning of production, and the other three parameters at harvest.

The duration of germination varies from $3 \pm 1$ days to $6 \pm 1$ days depending on the treatment applied. In the alkaline soils, the germination time is $3 \pm 1$ days [54]. The longest germination time is observed on the university campus soil with $10 \%$ biochar enriched and without mycorrhiza. The shortest is the one made up of enriched biochar and Beka soil. This is $3 \pm 1$ days regardless of the rate of mycorrhiza incorporated. These differences, however, are not significant at $p<0.05$ in the presence of enriched biochar added two soils considered separately. This means that in the presence of enriched biochar, the germination time does not significantly vary. The effect of the incorporated mycorrhizal level is also low. The incorporated mycorrhizae reduce the germination duration at 2 days in the university campus soil. There is no significant effect observed with Beka soil for the germination duration is the same for all the treatments. The soil being alkaline, neither the addition of the enriched biochar, nor that of the mycorrhiza, accelerates the emergence of the bean seedlings.

The total mass of dried bean stems varies from $510 \pm 40$ to $890 \pm 30 \mathrm{mg}$ for the university campus soil plants, and from $870 \pm 50$ to $900 \pm 50 \mathrm{mg}$ for the bean grown on the Beka soil. These differences between the two soils are attributable to the soil $\mathrm{pH}$, the first being acidic and the second alkaline. Acidic soils do hinder plants vegetative growth, unlike alkaline soils. On the other hand, the university campus soil is poor in organic matter and rich in iron and aluminium hydro-oxides that are likely to hinder the bean growth. The presence of mycorrhizae significantly affects the total mass of bean stems $(\mathrm{p}<0.05)$ on the university campus soil. The total mass of stems increases from $136 \pm 30 \mathrm{mg}$ to $230 \pm 32 \mathrm{mg}$ upon incorporation of $0.5 \%$ mycorrhizae. Already, at this incorporation rate, vegetative growth is boosted. On the Beka soil, this change is not revealed. The addition of mycorrhizae at a rate varying from $0 \%$ to $4 \%$ does not change the total mass of stems produced.

The total root mass ranges from $136 \pm 30$ to $450 \pm 30 \mathrm{mg}$ on the university campus soil, and from $470 \pm 50$ to $490 \pm 50 \mathrm{mg}$ on the Beka soil. With the presence of mycorrhizae, root production is boosted on the university campus soil. It goes from $136 \pm 30$ $\mathrm{mg}$ to $230 \pm 32 \mathrm{mg}$ when adding $0.5 \%$ mycorrhizae. This is estimated at almost $100 \mathrm{mg}$ at every additional $1 \%$ mycorrhizae and stabilizes when $3 \%$ mycorrhizae is added.

The bean roots size is influenced by the rate of mycorrhizae addition to the university campus soil. It varies from $4.82 \pm 0.5$ $\mathrm{cm}$ to $14 \pm 0.8 \mathrm{~cm}$ when the rate of incorporated mycorrhiza ranges from $0 \%$ to $4 \%$. The coefficient of variation is $34.5 \%$. No significant difference is observed for the Beka soil. It varies here from $14.2 \pm 0.5 \mathrm{~cm}$ to $14.5 \pm 0.2 \mathrm{~cm}$. The coefficient of variation is also low, it is $3.41 \%$. The root size may reflect the rate of mycorrhization. On the university campus soil, the growth of the root size significantly increases with the level of incorporated mycorhizae. The microbial activity can be stimulated in the presence of the enriched biochar. 
Table 3: Combined Effect of Biochar and Different Proportions of Mycorrhizae on Some Bean Growth Parameters on University Campus Soil.

\begin{tabular}{|c|c|c|c|c|c|c|c|c|}
\hline \multirow{2}{*}{ Parameters } & \multicolumn{6}{|c|}{ Proportion of incorporate mycorrhizae in soil } & \multirow{2}{*}{$\mathbf{C V}$} & \multirow{2}{*}{ p value } \\
\hline & control & $10 \% \mathrm{~EB}+0 \% \mathrm{MP}$ & $10 \% \mathrm{~EB}+1 \% \mathrm{MP}$ & $10 \% \mathbf{E B}+2 \% \mathrm{MP}$ & $10 \% \mathrm{~EB}+3 \% \mathrm{MP}$ & $10 \% \mathrm{~EB}+4 \% \mathrm{MP}$ & & \\
\hline Germination duration $[d]$ & $8 \pm 1^{\mathrm{a}}$ & $4 \pm 1^{b}$ & $4 \pm 1^{b}$ & $4 \pm 1^{\mathrm{b}}$ & $4 \pm 1^{b}$ & $4 \pm 1^{b}$ & $29,61 \%$ & 0,3149 \\
\hline DM total stalk [mg] & $510 \pm 40^{\mathrm{b}}$ & $720 \pm 50^{\mathrm{ab}}$ & $830 \pm 50^{\mathrm{a}}$ & $850 \pm 50^{\mathrm{a}}$ & $850 \pm 50^{\mathrm{a}}$ & $890 \pm 50^{\mathrm{a}}$ & $18,12 \%$ & 0,0000 \\
\hline DM total roots $[\mathrm{mg}]$ & $136 \pm 30^{c}$ & $230 \pm 32^{\text {bc }}$ & $340 \pm 35^{\mathrm{ab}}$ & $440 \pm 30^{\mathrm{a}}$ & $450 \pm 30^{\mathrm{a}}$ & $450 \pm 30^{\mathrm{a}}$ & $37,52 \%$ & 0,0000 \\
\hline Root's size [cm] & $4,82 \pm 0,5^{\mathrm{c}}$ & $7,25 \pm 0,6^{\mathrm{c}}$ & $10,5 \pm 0,7^{\mathrm{b}}$ & $13,6 \pm 0,7^{\mathrm{a}}$ & $13,7 \pm 0,5^{\mathrm{a}}$ & $14 \pm 0,8^{\mathrm{a}}$ & $34,5 \%$ & 0,0000 \\
\hline
\end{tabular}

The values followed by the same lowercase letters are not significantly different; the values of $p$ are calculated at different percentages and reported in a line.

Légende $: \mathrm{CV}=$ coefficient de variation; $\mathrm{p}=$ probabilité ; DM = Dry mater

Table 4: Combined Effect of Biochar and Different Proportions of Mycorrhizae on Some Bean Growth Parameters on Beka Soil.

\begin{tabular}{|c|c|c|c|c|c|c|c|c|}
\hline \multirow[b]{2}{*}{ Parameters } & \multicolumn{6}{|c|}{ Proportion of incorporate mycorrhizae in soil } & \multirow[b]{2}{*}{$\mathbf{C V}$} & \multirow{2}{*}{$\begin{array}{c}\mathbf{p} \\
\text { value }\end{array}$} \\
\hline & control & $10 \% \mathrm{~EB}+0 \% \mathrm{MP}$ & $10 \% \mathrm{~EB}+1 \% \mathrm{MP}$ & $10 \% \mathrm{~EB}+2 \% \mathrm{MP}$ & $10 \% \mathrm{~EB}+3 \% \mathrm{MP}$ & $\begin{array}{c}10 \% \mathrm{~EB}+4 \% \\
\mathrm{MP}\end{array}$ & & \\
\hline $\begin{array}{l}\text { Germination } \\
\text { duration [d] }\end{array}$ & $3 \pm 1^{\mathrm{a}}$ & $3 \pm 1^{\mathrm{a}}$ & $3 \pm 1^{\mathrm{a}}$ & $3 \pm 1^{\mathrm{a}}$ & $3 \pm 1^{\mathrm{a}}$ & $3 \pm 1^{\mathrm{a}}$ & $28 \%$ & 1,0000 \\
\hline $\begin{array}{l}\text { DM total stalk } \\
{[\mathrm{mg}]}\end{array}$ & $870 \pm 50^{\mathrm{a}}$ & $870 \pm 50^{\mathrm{a}}$ & $890 \pm 50^{\mathrm{a}}$ & $890 \pm 50^{\mathrm{a}}$ & $900 \pm 50^{\mathrm{a}}$ & $900 \pm 50^{\mathrm{a}}$ & $18,74 \%$ & 0,6039 \\
\hline $\begin{array}{l}\text { DM total roots } \\
{[\mathrm{mg}]}\end{array}$ & $470 \pm 42^{\mathrm{a}}$ & $470 \pm 42^{\mathrm{a}}$ & $470 \pm 42^{\mathrm{a}}$ & $470 \pm 50^{\mathrm{a}}$ & $490 \pm 55^{\mathrm{a}}$ & $490 \pm 55^{\mathrm{a}}$ & $8,21 \%$ & 0,973 \\
\hline $\begin{array}{l}\text { Root's size } \\
{[\mathrm{cm}]}\end{array}$ & $14,20 \pm 0,5^{\mathrm{a}}$ & $14,20 \pm 0,5^{\mathrm{a}}$ & $14,20 \pm 0,5^{\mathrm{a}}$ & $14,50 \pm 0,5^{\mathrm{a}}$ & $14,5 \pm 0,5^{\mathrm{a}}$ & $14,5 \pm 0,2^{\mathrm{a}}$ & $3,41 \%$ & 0,8977 \\
\hline
\end{tabular}

The values followed by the same lowercase letters are not significantly different; the values of p are calculated at different percentages and reported in a line.

Legend: $C V=$ coefficient of variation; $p=$ probability; DM= Dry mater

Combined effect of enriched biochar and proportion of incorporated mycorrhizae on stem size evolution

Figures 1 and 2 show respectively the variation of stem size as a function of the proportion of mycorrhizae incorporated in the university campus and Beka soils. On the university campus soil, the smallest size observed is $8 \mathrm{~cm}$ (at the first week without mycorrhiza) and the longest is $65.8 \mathrm{~cm}$ (the 5 th week with a $4 \%$ mycorrhizae). All plants have growth parameters similar at the first week. At the end of the second week, three types of stem growth are observed. The first type is that of the control (soil without enriched biochar and without mycorrhiza), the second is that of the two treatments (incorporation of biochar enriched with $0 \%$ and $1 \%$ of mycorrhiza), the third is that of three other treatments (incorporation of biochar enriched with $2 \%, 3 \%$ and $4 \%$ of mycorrhiza). It is at the end of the 4 th week that the effects of different proportions of mycorrhizae are revealed.

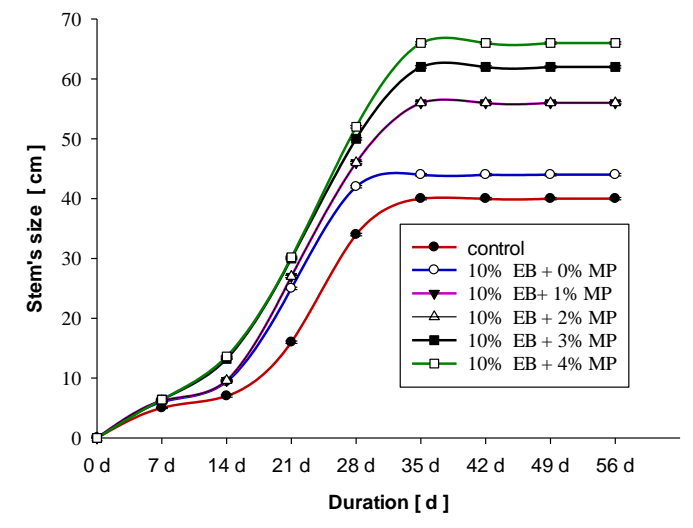

Figure 1: Variation of stem size based on proportion of incorporated mycorrhizae and time (University Campus Soil)

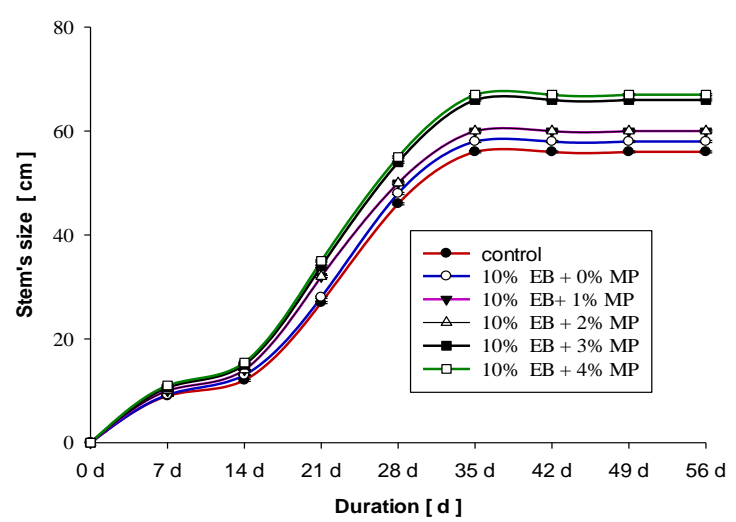

Figure 2: Variation of stem size based on proportion of incorporated mycorrhizae and time (Beka's Soil)

This slight difference during the first week is even more pronounced with the Beka soil. It is minimal for the pot without mycorrhiza $(9 \mathrm{~cm})$ and maximum $(11 \mathrm{~cm})$ for the pot containing $4 \%$ of mycorrhizae. The same observation is done on the soil of the university campus. In general, growth is rapid during the first four weeks and decreases from the fifth week. This can be explained by the fact that the bean has begun to complete its vegetative growth to trigger flowers and seeds production. The presence of mycorrhizae in Beka does not affect seedling growth. Here, the variation of the diameter size is more influenced by the time than the level of incorporated mycorhizae. The addition of mycorrhizae only slightly modifies the growth of stem's diameter because Beka soil is naturally rich in nutrients and present optimal physicochemical parameters. 
Combined effect of enriched biochar and the proportion of incorporated mycorrhizae on the variation of the stem diameter's size.

Figures 3 and 4 show the variation the stem diameter's size as function of the level of incorporated mycorhizae at the collar and time. A maximum stem diameter of $1.2 \mathrm{~mm}$ is recorded on plants raised on the university campus soil, against a maximum diameter of $1.6 \mathrm{~mm}$ on the Beka soil. For the university campus soil, during the first week, a proportion of $1 \%$ of mycorrhiza already allows to increase the diameter at the neck. Thus, a difference is observed between the bean seedlings that received no mycorrhizae compared to the others that received mycorrhizae. On the other hand, on the Beka soil, the evolution of the seedlings does not allow us to conclude that mycorrhizae have an effect on the diameter of the stem at the neck.

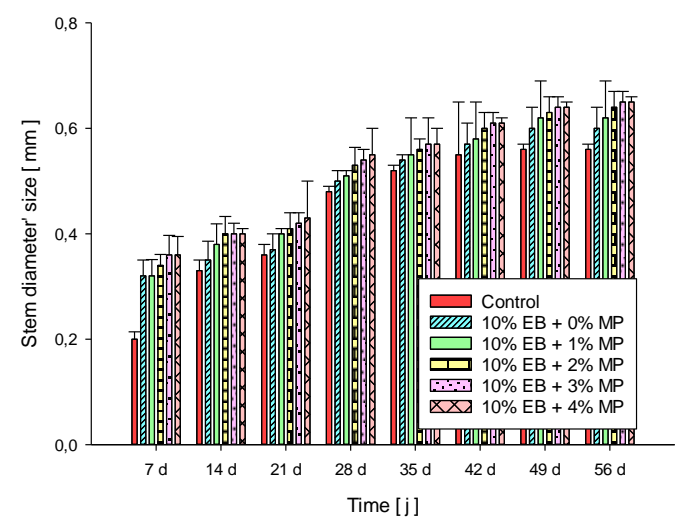

Figure 3: Stems diameter as a function of incorporated mycorrhizal proportion and time (university campus soil)

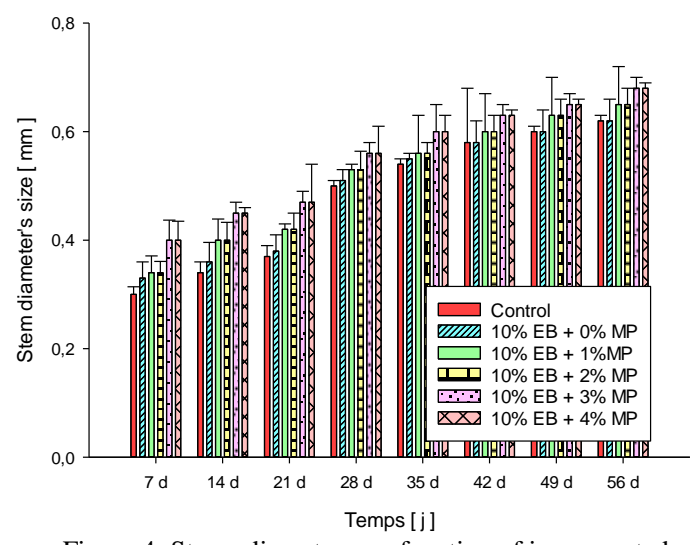

Figure 4: Stems diameter as a function of incorporated mycorrhizal proportion and time (Beka soil)

Combined effect of enriched biochar and proportion of incorporated mycorrhiza on the cumulative number of leaves.

Tables 5 and 6 present respectively the evolution of the cumulative number of leaves of seedlings grown on the university campus and Beka soil. The total number of leaves produced for different treatments of the university campus soil varies from $10 \pm 1$ for the control soil (soil without enriched biochar and without mycorrhiza) to $18 \pm 1$ at the end of the vegetative growth. The bean plants stop leaves production after 4 weeks. For the bean seedlings grown on the Beka soil, the total number of leaves produced for the various treatments ranges from $16 \pm 1$ for the control soil (soil without enriched biochar and without mycorrhiza) to $20 \pm 1$ at the end of the vegetative growth. Also on this soil, bean plants stop the leaves production at the end of the 4th week. The control soil of the university campus produces the lowest number of leaves. This can be linked to the poor quality of this soil and its low $\mathrm{pH}$. Addition of enriched biochar alone increases the production of leaves, which increase the number of leaves from 10 to 15 leaves. On the other hand, on the first week, only the control soil treatment showed a 2-to-5 leaves yield for all other treatments. The low leaves production can be attributed to the lack of enriched biochar and the mycorrhizal inoculum. The addition of another biofertilizer, namely mycorrhiza, makes it possible to change the foliar production, which then reaches the number of 18 leaves at the end of the 4th week. The difference between the control and the treatment with more biochar and mycorrhizae in terms of leaves number at the end of foliar production is 8 leaves.

The effect of enriched biochar and different proportions of mycorrhiza appears to be lower on Beka soil. The variation coefficient does not exceed 10\%. In the first week, all treatments (including control soil) produced 5 leaves (coefficient of variation was $0 \%$ ). This can be explained by the fact that, the Beka soil is rich in nutrients; it has an alkaline $\mathrm{pH}$ and an optimal cation exchange capacity for foliar evolution of the bean plant. The addition of the mycorrhizal inoculum seems to bring about little difference in terms of foliar production because the maximum difference is 4 leaves at the end of vegetative growth between the control and the treatment with more biochar and mycorrhizae. 
Table 5: Combined effect of biochar and proportion of mycorrhizae on progression of cumulative number of leaves (University Campus Soil).

\begin{tabular}{|c|c|c|c|c|c|c|c|}
\hline \multirow{2}{*}{ Time } & \multicolumn{6}{|c|}{ Proportions of enriched Biochar and incorporated mycorrhizae } & \multirow[t]{2}{*}{ CV } \\
\hline & control & $10 \% \mathrm{~EB}+0 \% \mathrm{MP}$ & $10 \% \mathrm{~EB}+1 \% \mathrm{MP}$ & $10 \% \mathrm{~EB}+2 \% \mathrm{MP}$ & $10 \% \mathrm{~EB}+3 \% \mathrm{MP}$ & $10 \% \mathrm{~EB}+4 \% \mathrm{MP}$ & \\
\hline 1st wk. & $2 \pm 0 \mathrm{~b}$ & $5 \pm 0 \mathrm{a}$ & $5 \pm 0 \mathrm{a}$ & $5 \pm 0 \mathrm{a}$ & $5 \pm 0 \mathrm{a}$ & $5 \pm 0 \mathrm{a}$ & $25,56 \%$ \\
\hline 2st wk. & $5 \pm 0 \mathrm{~b}$ & $8 \pm 0 \mathrm{a}$ & $8 \pm 0 \mathrm{a}$ & $8 \pm 0 \mathrm{a}$ & $8 \pm 0 \mathrm{a}$ & $8 \pm 0 \mathrm{a}$ & $25,56 \%$ \\
\hline 3st wk. & $8 \pm 0 \mathrm{e}$ & $12 \pm 0 \mathrm{~d}$ & $13 \pm 0 \mathrm{c}$ & $14 \pm 0 \mathrm{~b}$ & $14 \pm 0 \mathrm{~b}$ & $15 \pm 0 \mathrm{a}$ & $18,56 \%$ \\
\hline 4st wk. & $10 \pm 1 b$ & $15 \pm 1 \mathrm{a}$ & $16 \pm 1 \mathrm{a}$ & $16 \pm 1 \mathrm{a}$ & $17 \pm 1 \mathrm{a}$ & $18 \pm 1 \mathrm{a}$ & $18,03 \%$ \\
\hline
\end{tabular}

Values followed by the same lowercase letters are not significantly different; $p$ values are calculated at different percentages and reported in a row, Tukey HSD at $99.99 \%$

Legend BE = Biochar Enriched; PM = Proportion of Mycorrhizae; CV = coefficient of variation; wk. = week

Table 6: Combined effect of biochar and proportion of mycorrhizae on progression of cumulative number of leaves (Beka Soil).

\begin{tabular}{|c|c|c|c|c|c|c|c|}
\hline \multirow{2}{*}{ Time } & \multicolumn{6}{|c|}{ Proportions of enriched Biochar and incorporated mycorrhizae } & \multirow[t]{2}{*}{ CV } \\
\hline & control & $10 \% \mathbf{E B}+0 \% \mathrm{MP}$ & $10 \% \mathrm{~EB}+1 \% \mathrm{MP}$ & $10 \% \mathrm{~EB}+2 \% \mathrm{MP}$ & $10 \% \mathrm{~EB}+3 \% \mathrm{MP}$ & $10 \% \mathrm{~EB}+4 \% \mathrm{MP}$ & \\
\hline 1st wk. & $5 \pm 0 \mathrm{a}$ & $5 \pm 0 \mathrm{a}$ & $5 \pm 0 \mathrm{a}$ & $5 \pm 0 \mathrm{a}$ & $5 \pm 0 \mathrm{a}$ & $5 \pm 0 \mathrm{a}$ & $0 \%$ \\
\hline 2st wk. & $8 \pm 0 \mathrm{a}$ & $8 \pm 0 \mathrm{a}$ & $8 \pm 0 \mathrm{a}$ & $8 \pm 0 \mathrm{a}$ & $8 \pm 0 \mathrm{a}$ & $8 \pm 0 \mathrm{a}$ & $0 \%$ \\
\hline 3st wk. & $13 \pm 0 \mathrm{~d}$ & $14 \pm 0 \mathrm{c}$ & $14 \pm 0 \mathrm{c}$ & $14 \pm 0 \mathrm{c}$ & $15 \pm 0 \mathrm{~b}$ & $16 \pm 0 \mathrm{a}$ & $6,71 \%$ \\
\hline 4st wk. & $16 \pm 1 \mathrm{a}$ & $17 \pm 1 \mathrm{a}$ & $18 \pm 1 \mathrm{a}$ & $18 \pm 1 \mathrm{a}$ & $20 \pm 1 \mathrm{a}$ & $20 \pm 1 \mathrm{a}$ & $9,48 \%$ \\
\hline
\end{tabular}

Values followed by the same lowercase letters are not significantly different; $p$ values are calculated at different percentages and reported in a row, Tukey HSD at $99.99 \%$

Legend $:$ BE = Biochar Enriched; $\mathrm{PM}=$ Proportion of Mycorrhizae; $\mathrm{CV}=$ coefficient of variation; wk. = week

\section{Combined effect of enriched biochar and proportion of mycorrhizae incorporated on pod production}

Figures 5 and 6 show the number of pods in terms of treatments in the soil of the university campus and the Beka soil, respectively. In the soil of the university campus, the number of pods produced per plant is minimal (10 \pm 2$)$ in the control soil (without incorporation of the enriched biochar and without incorporation of mycorrhizae), the highest number of pods is obtained on the plants. Receiving 10\% enriched biochar and $4 \%$ mycorrhiza. The comparison of the averages of the treatments carried out from this soil by the analysis of the variance reveals a significant difference $(\mathrm{P}=0.028)$ between the treatments. The Tukey HSD test distinguishes 5 groups of difference (Figure 9). In Beka soil, the minimum number of pods (20 \pm 2 ) is obtained in the control soil and the mixture of soil and enriched biochar $(10 \%)$ in the absence of mycorrhizae. The maximum number (22 \pm 2$)$ is obtained on treatments of $10 \%$ biochar enriched with 3 or $4 \%$ of mycorrhizae. The comparison of treatment averages versus pod numbers by variance analysis shows that there is no significant difference between varieties $(P=0.366)$. This can be explained by the fact that the Beka soil is already sufficiently rich and has the necessary physic-chemical properties (for example the $\mathrm{pH}$ is basic), the addition of the two biofertilizers do not influence pod production.

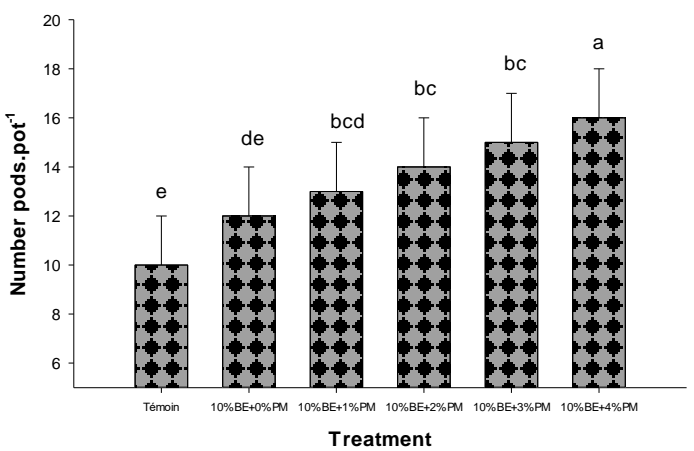

Figure 5: Production of pods according to treatments (University campus soil).

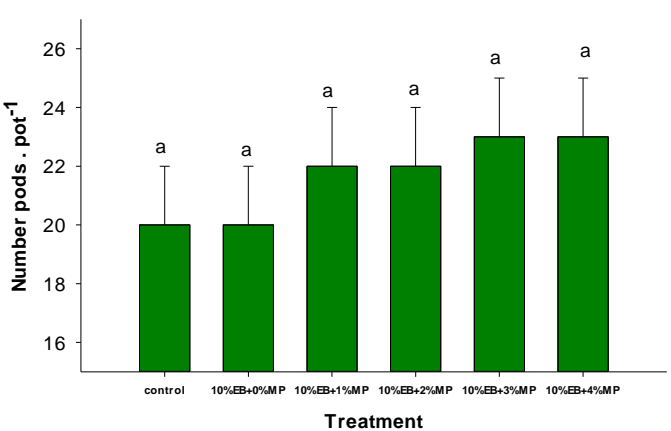

Figure 6: Production of pods according to treatments (Beka soil).

Combined effect of enriched biochar and mycorrhiza on dry grain yield

Figure 7 shows the combined effect of enriched biochar and mycorrhiza on dry grain yield of bean plants grown on the university campus soil. Comparing the averages of treatments to dry grain yield by the analysis variance reveals a significant difference $(\mathrm{P}=0.000)$ between treatments. The Tukey HSD test shows three distinct groups of difference. Treatments of this soil 
with the addition of $10 \%$ biochar and $3 \%$ or $4 \%$ mycorrhizae (group a). This group gives a high average with respectively $60 \pm 4$ g.pot ${ }^{-1} ; 64 \pm 4$ g.pot ${ }^{-1}$ when switching from 3 to $4 \%$ mycorrhizae while maintaining the incorporation rate of $10 \%$ biochar. The second group (group b) brings together three treatments. It gives an intermediate average. The dry grain yield per treatment is $33.6 \pm 1.4$ g.pot ${ }^{-1} ; 31.2 \pm 2.4$ g.pot ${ }^{-1}$ and $28.8 \pm 4.8$ g.pot $^{-1}$ respectively for an incorporation of $2 ; 1$ and $0 \%$ mycorrhizal but with a $10 \%$ incorporation of biochar maintained in all three treatments. The last group (group c) has only one treatment (control treatment). It gives a very low average of $8.8 \pm 1.7 \mathrm{~g}_{\text {. pot }}{ }^{-1}$. The differences in yield observed are due to the fact that the number of grains contained in the pods and the grain weight of the treatments differs. A high number of grains (averaged 8 grains) per pod is recorded in treatments with 3 and $4 \%$ incorporation of mycorrhizae, average (6 grains per pod) in treatments with $1 \%$ incorporation; $2 \%$ mycorrhizal or none but a biochar incorporation rate of $10 \%$. The university campus control soil presents the lower number of grains per pod, it averages 4 grains per pod. Grain weighing of the various treatments revealed a high mass when the biochar and/or mycorrhizae are incorporated (on average $0.4 \mathrm{~g}$ ) compared to a low mass in the control soil plants (on average $0.125 \mathrm{~g}$ ). Thus, the addition of biochar and / or mycorrhizal makes it possible to obtain a higher number of seeds per pod and grains of higher mass. The enriched biochar and the biological activities of mycorrhizae provide the bean plant with nutrients necessary for optimal development of pods and grains.

Figure 8 shows the cumulative effect of enriched biochar and mycorrhiza on bean plants in Beka soil. A comparison of average treatments versus dry grain yield by ANOVA reveals a significant difference $(\mathrm{P}=0.000)$ between treatments. The Tukey HSD test, however, distinguishes only two groups. The first group (group a) includes treatments that received a mycorrhizal level of 3 and $4 \%$ in the presence of $10 \%$ enriched biochar. The average yield of this group of $176 \pm 8$ g.pot $^{-1}$. The second group (group b) comprises all other treatments, including the control. The yield is between $120 \pm 12 \mathrm{~g}$ pot $^{-1}$ and $126 \pm 6 \mathrm{~g}^{\mathrm{p} p \mathrm{t}^{-1}}$. An observation of the pods and grains obtained with Beka soil or mixtures reveals on the one hand that the number of grains is constant ( 6 grains per pod). The grain weight fluctuates between 0.35 and $0.4 \mathrm{~g}$. Thus, the incorporation of enriched biochar or mycorrhiza does not significantly affect yield when a soil is already rich in nutrients such as the Beka soil.

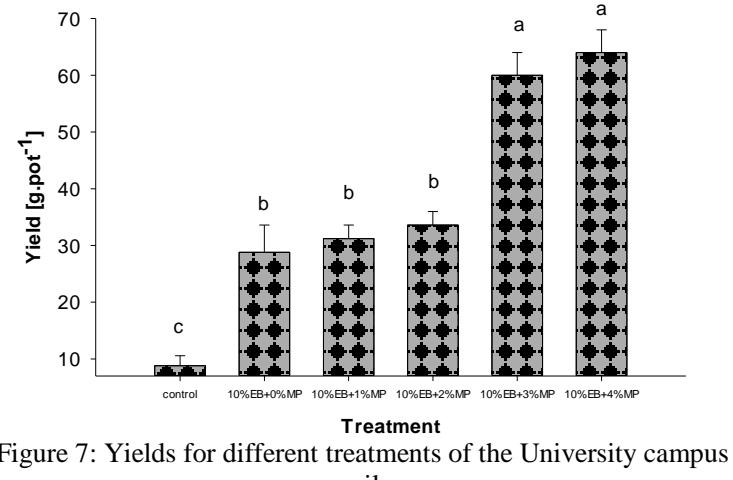
soil.

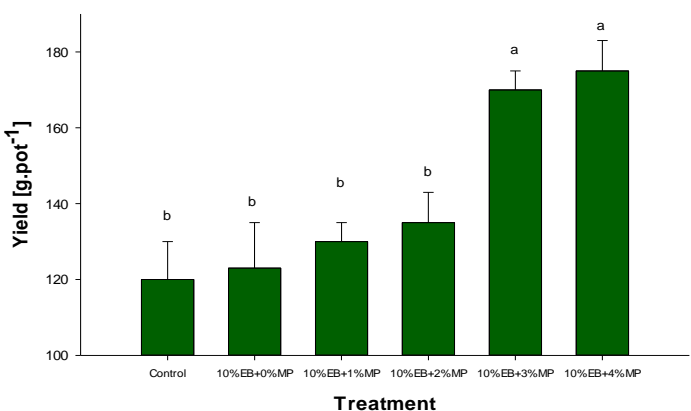

Figure 8: Yield for different treatments of Beka soil.

\section{CONCLUSION}

The study is primarily aiming at evaluating the influence of enriched biochar on the physicochemical properties of the two contrasting soils, and to determine the combined effect enriched biochar and mycorrhiza on bean crops production.

The analysis of the few bean production factors on the two control soils and their mixtures with the enriched biochar and / or mycorrhiza reveals that the two biofertilizers mainly affect the poor and acidic university campus soil. Incorporation of enriched biochar and / or mycorrhiza improved vegetative growth of the bean (stem and root sizes, stem diameter at collar, mass of stems and roots) as well as pod yield and in grains per plant. The enriched biochar and / or the mycorrhizae thus make it possible to harvest a large number of pods, a high number of seeds per pod, and grains of higher mass. Both in acidic soils of the university campus and in the alkaline Beka soil, the proportion of mycorrhizae can be reduced by adding enriched biochar without affecting the bean grains yield. However, the bean plants grown on Beka soil reacted only slightly to the incorporation of enriched biochar and / or mycorrhiza compared to the University campus soil. The use of a combination of enriched biochar and mycorrhizae could be a good alternative to the use of chemical fertilizers on acidic soils. Also, the enriched biochar allow for the reduction of the quantities of mycorrhizae necessary and thereby reduces production costs.

\section{ACKNOWLEDGMENT}

We thank the special fund of support for the modernization of research of the Ministry of Higher Education of Cameroon, which allowed us the feasibility of this study.

\section{REFERENCES}

[1] Cattaneo, F., Di Gennaro, P., Barbanti, L., Giovannini, C., Labra, M., Moreno, B., Baudoin J.P., Vanderborght T., Kimani P.M. et Mwang'ombe A.W., 2001. Les légumineuses à grain: Le Haricot commun. In: Reamaeker R. H. (éditeurs) 317-334pp.

[2] Nyabyenda P., 2005. Les plantes cultivées en régions tropicales d'altitudes d'Afrique: Généralités, Légumineuses alimentaires, Plantes à tubercules et racines, Céréales. Presses agronomiques de Gembloux, Bruxelles, 225p

[3] CIAT. 2005. Application de la biotechnologies à la lutte contre les maladies du haricot. N²7; Le CIAT en Enrique. 
[4] Institut National de la Statistique, 2013. Annuaire statistique du Cameroun: recueil des séries d'informations statistiques sur les activités économiques, sociales, politiques et culturelles du pays jusqu'en 2013, Yaoundé, Cameroun, $536 \mathrm{p}$

[5] IITA, 1989. Annual Report and Research Highlight. IITA, Ibadan 50p

[6] Nwaga D., 2000. Agriculture biologique ET alternative de la biofertilisation. In: utilisation des biofertilisants microbiens pour la culture durable. Premier atelier de formation organisé par l'UMAB. Université de Yaoundé I, du 31 mars au 1 ${ }^{\text {er }}$ avril 2000. Pp 23 à 24.

[7] Tisdall J. M. 1991. Fungal hyphae and structural stability of soil. Australian Journal of Soil Research 159: 115-121

[8] Caravaca, F., Alguacil, M. M., Azcon, R. and Roldan, A. 2006. Formation of stable aggregates in rhizosphere soil of Juniperus oxycedrus: Effect of AM fungi and organic amendments. Applied Soil Ecology, 33, pp. 30-38.

[9] Rillig, M. C., Mardatin, N. F., Leifheit, E. F. and Antunes, P. M. 2010. Mycelium of arbuscular mycorrhizal fungi increases soil water repellency and is sufficient to maintain water- stable soil aggregates. Soil Biology and Biochemistry, 42, pp. 1189- 1191.

[10] Saito, M. 1990. Charcoal as a microhabitat for VA mycorrhizal fungi, and its practical implication. Agriculture Ecosystems and Environment, 29 , pp. 341-344.

[11] Bakhtiar Y, Yahya S, Sumaryona W, Sinaga MS, Budi SW, Tajudin T. 2010. Isolation and identification of mycorhizosphere bacteria and their antagonistic effects towards Ganoderma boniense in vitro. Journal of Microbiology Indonesia 4(2): 96-102.

[12] Lehman, J, Rillig M, Thies J, Masiello CA, Hockaday WC, Crowley D, 2011, Biochar effects on soil biota - a review, Soil Biol Biochem; $43: 1812-36$

[13] Blackwell P, Joseph S, Munroe P, Anawar H M, Storer P, Gilkes R. J, Solaiman Z M. 2015. Influences of Biochar and Biochar-Mineral Complex on Mycorrhizal Colonization and Nutrition of Wheat and Sorghum. Pedosphere 25 (5): 686-695.

[14] Solaiman Z M, Blackwell P, Abbott L K, Storer P. 2010. Direct and residual effect of biochar application on mycorrhizal root colonisation, growth and nutrition of wheat. Aust J Soil Res. 48: 546-554

[15] Pietikäinen J, Kiikkilä O, Fritze H. 2000. Charcoal as a habitat for microbes and its effect on the microbial community of the underlying humus Oikos. 89: 231-242.

[16] Blackwell P, Riethmuller G, Collins M. 2009. Biochar application to soil. In Lehmann J, Joseph S (eds.) Biochar for Environmental Management: Science and Technology. Earthscan, London. pp. 207-226.

[17] Roberts K G, Gloy B A, Joseph S, Scott N R, Lehmann J. 2010. Life cycle assessment of biochar systems: estimating the energetic, economic, and climate change potential. Environ Sci Technol. 44: 827-833

[18] Ortas I, 2016. Role of mycorrhizae and biochar on plant growth and soil quality. In Biochar, a Regional Supply Chain Approach in View of Climate Change Mitigatıon., Eds. Bruckman VJ, Varol EA, Uzun BB, Liu JF, p. 398. Cambridge Universitey Press, Cambridge, UK

[19] Steiner C, Teixeira WG, Lehmann J, Nehls T, Vasconcelos de Macêdo JL, Blum WEH, Zech W. 2007. Long term effects of manure, charcoal and mineral fertilization on crop production and fertility on a highly weathered Central Amazonian upland soil. Plant and Soil 291: 275-290.

[20] Van Zwieten L, Kimber S, Morris S, Chan KY, Downie A, Rust J. 2010, Effects of biochar from slow pyrolysis papermill waste on agronomic performance and soilfertility, Plant Soil, 320:235-46.

[21] Chan K Y, Cu Z. 2009. Biochar: nutrient properties and their enhancement. In Lehmann J, Joseph S (eds.) Biochar for Environmental Management: Science and Technology. Earthscan, London. pp. 67-84.

[22] Liang B, Lehmann J, Kinyangi D, Grossman J, O’Neill B, Skjemstad JO,Thies J, Luizao FJ, Peterson J, Neves EG. 2007 Black carbon increases cation exchange capacity in soils. Soil Science Society of America Journal 70, 1719-1730. doi: 10.2136/sssaj2005.0383

[23] Steinbeiss, S., Gleixner, G., Antonietti, M., 2009. Effect of biochar amendment on soil carbon balance and soil microbial activity. Soil Biol. Biochem. 41, 1301-1310.

[24] Blackwell P, Riethmuller G, Collins M. 2009. Biochar application to soil. In Lehmann J, Joseph S (eds.) Biochar for Environmental Management: Science and Technology. Earthscan, London. pp. 207-226.

[25] Warnock, D.D., Lehmann, J., Kuyper, T.W., Rillig, M.C. 2007. Mycorrhizal responses to biochar in soil - concepts and mechanisms. Plant Soil $300,9-20$

[26] Karandashov, V. and Bucher, M. 2005. Symbiotic phosphate transport in arbuscular mycorrhizas. Trends in Plant Science, 10 , pp. $22-29$.

[27] Smith, S. E. and Read, D. J. 2008. Mycorrhizal Symbiosis. 3rd Edition. San Diego, CA: Academic Press.

[28] Ortas, I., Akpinar, C. and Lal, R. 2013. Long- term impacts of organic and inorganic fertilizers on carbon sequestration in aggregates of an Entisol in Mediterranean Turkey. Soil Science, 178, pp. 12-23

[29] Hammer, E.C., Balogh-Brunstad, Z., Jakobsen, I., Olsson, P.A., Stipp, S.L.S., Rillig, M.C., 2014. A mycorrhizal fungus grows on biochar and captures phosphorus from its surfaces. Soil Biol. Biochem. 77, 252-260

[30] Warnock DD, Mummey DL, McBride B, Major J, Lehmann J, Rillig MC. 2010. Influences of non-herbaceous biochar on arbuscular mycorrhizal fungal abundances in roots and soils: results from growth-chamber and field experiments. Appl Soil Ecol 46:450-456

[31] Downie A, Crosky A, Munroe P. 2009. Physical properties of biochar. In: Lehmann J, Joseph S (Eds) Biochar for environmental management, science and technology. Earthscan, London, pp.

[32] Jaafar N.M. 2014. Biochar as a habitat for Arbuscular Mycorrhizal Fungi. In: Solaiman Z., Abbott L., Varma A. (Eds) Mycorrhizal Fungi; Use in Sustainable Agriculture and Land Restoration. Soil Biology, vol 41. Springer, Berlin, Heidelberg

[33] CDDR/SAILD, 2016. Culture du haricot rouge Ou haricot commun (Phaseolus vulgaris). Synthase technique. 6p.

[34] SAILD, 1998. Recueil de fiches technique pour l'entrepreneur rural. Tome 1. Yaoundé, Cameroun. 75p.

[35] Rajkovich S, Enders A, Hanley K, Hyland C, Zimmerman AR, Lehmann J. 2011. Corn growth and nitrogen nutrition after additions of biochars with varying properties to a temperate soil. Biology and Fertility of Soil 48:271-284

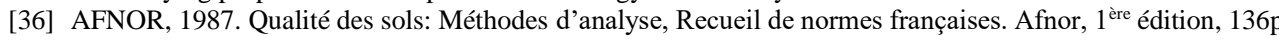

[37] AFNOR, 1995. Qualité du sol - Détermination de la conductivité électrique, NF ISO 11265 - Indice de classement: X31-113. Paris, France, $8 \mathrm{p}$.

[38] AFNOR. 1993. NFX 31-130. Détermination de la capacité d'échange cationique et des cations extractibles.

[39] AFNOR, 1984. Recueil de normes françaises. Produits agricoles alimentaires : directives générales pour le dosage de l'azote avec minéralisation selon la méthode de Kjedahl. AFNOR, Paris (France).

[40] Devani, M.B., Shisha, Shah, S.A. ET Shadier, B.N. 1989. Spectrophometric for micro determination of nitrogen in Kjedahl disgest. J. assoc. office. Anal. Chem., 72 (6) 953-956.

[41] Rodier J. 2009. Analyse de l'eau, Dunod, Paris, 1579p

[42] AFNOR, 1986. Recueil de normes françaises. Eau - Méthodes d'essai. AFNOR, Paris (France).

[43] Megueni C, Ngakou A, Makalao MM, Kameni TD, 2006. Response of soybean (Glycine max L.) to soil solarization and rhizobial inoculation at Dang Ngaoundéré, Cameroun. Asian Journal of plant Science 5 (5): 832-837

[44] Risppstein G., 1985. Etude sur la végétation de l'Adamaoua. Evolution, conservation, régénération ET amélioration d'un écosystème pâturé au Cameroun. Etude et synthèse de l'E.M.V.T. N ${ }^{\circ} 14$. Maison Alfort, 367p.

[45] Fezeu, Wombuwou M. L., 2006, Statut minéral des sols, des plantes, des eaux d'abreuvage et de bovins du pâturage de Wakwa au Cameroun, thèse, Université de Ngaoundéré, Laboratoire de Sciences Alimentaires et Nutrition, 253p. 
[46] Beesley L, Marmiroli M. 2011. The immobilisation and retention of soluble arsenic, cadmium and zinc by biochar. Environmental Pollution 159: 474-480.

[47] Mathieu, C., Pieltain, F., 2003, Analyse chimique des sols. Méthodes choisies. Ed. Tec \& Doc; 382 pages

[48] Saxena J., Rana G., Pandey, M. 2013. Impact of addition of biochar along Bacillus sp. on growth and yield of French beans. Scienta Horticulturae, 162: 351-356.

[49] Yuan J. H., Xu R.K., Wang N., Li J.Y. 2011. Amendment of Acid Soils with Crop Residues and Biochars. Pedosphere, 21(3): $302-308$.

[50] Durand J.H., 1983. Les sols irrigables. Etude pédologique. Presses Universitaires de France. Agence de coopération culturelle et Technique. 338

[51] Adjia, R., Fezeu, W.M.L., Tchatchueng, J.B., Sorho, S., Ngassoum, M.B., 2010. Heavy Metals in five leafy vegetables from urban and periurban sites in Ngaoundéré, Cameroon. Iranica Journal of Energy \& Environment 1 (2): 124-131

[52] Noubissié, R.; 2015, spéciation des composés organométalliques $(\mathrm{Hg}, \mathrm{Sn}, \mathrm{Pb})$ dans les sols des cultures maraîchères et dans trois espèces de plantes à Ngaoundéré (Cameroun), thèse, Université de Ngaoundéré, Laboratoire de Chimie Industrielle ET Environnement, 213p

[53] Troeh, F. R. and Thompson, L. M., 2005. Soils and Soil Fertility, Blackwell Publishing, Iowa, US

[54] Ministère de la Coopération, 1991. Memento de l'Agronome, St-Just-la-Pendue, France1633 pp. 